\title{
Evaluation of pyraclostrobin and acibenzolar-S-methyl on common bacterial blight of snap bean
}

\author{
Avaliação de pyraclostrobin e acibenzolar-S-methyl sobre o \\ crestamento bacteriano comum do feijão-vagem
}

\author{
Sandra Cristina Vigo ${ }^{1}$; Antonio Carlos Maringoni ${ }^{2 *}$; \\ Renata de Cássia Camara ${ }^{3}$; Giuseppina Pace Pereira Lima ${ }^{4}$
}

\begin{abstract}
Assays were done under greenhouse conditions in order to evaluate the effect of pyraclostrobin $(0.0375$, 0.0750 and $\left.0.150 \mathrm{~mL} . \mathrm{L}^{-1}\right)$ and acibenzolar-S-methyl (ASM) $\left(0.025 \mathrm{~g} . \mathrm{L}^{-1}\right)$ in common bacterial blight on leaves of snap beans cultivar Bragança. These chemicals were sprayed at three different times: five days before; five days before + five days after; and five days after leaf inoculation with an isolate of Xanthomonas axonopodis pv. phaseoli. They were determinate the levels of polyphenoloxidase, peroxidase and total soluble proteins on inoculated and non-inoculated leaves of snap beans sprayed with pyraclostrobin $\left(0.075\right.$ g. $\left.\mathrm{L}^{-1}\right)$ and ASM $\left(0.025\right.$ g.L. $\left.\mathrm{L}^{-1}\right)$. All concentration of pyraclostrobin and ASM reduced the area under the disease progress curve (AUDPC) on leaves of snap beans, and the least AUDPC value was observed when this products were sprayed five days before + five days after inoculation. Higher levels of polyphenoloxidase, peroxidase and the total soluble proteins were observed on leaves sprayed with pyraclostrobin or ASM.
\end{abstract}

Key words: Phaseolus vulgaris, Xanthomonas axonopodis pv. phaseoli, protein

\section{Resumo}

Ensaios foram conduzidos sob condições de casa-de-vegetação para avaliar o efeito de pyraclostrobin $\left(0,0375 ; 0.0750\right.$ e $\left.0,150 \mathrm{~mL} . \mathrm{L}^{-1}\right)$ e acibenzolar-S-methyl (ASM) $\left(0.025\right.$ g.L $\left.\mathrm{L}^{-1}\right)$ sobre o crestamento bacteriano comum em folhas de feijão-vagem cultivar Bragança. Os produtos foram pulverizados em três diferentes períodos: cinco dias antes, cinco dias antes + cinco dias após e cinco dias após a inoculação dos folíolos com um isolado de Xanthomonas axonopodis pv. phaseoli. Foram determinados os teores de polifenoloxidase, peroxidase e proteínas solúveis totais em folhas inoculadas e nãoinoculadas de feijão-vagem pulverizadas com pyraclostrobin $(0,075$ g.L-1) e ASM ( 0,025 g.L-1). Todas as concentrações de pyraclostrobin e ASM reduziram os valores da área abaixo da curva do progresso da doença (AUPDC) e o menor valor da AUPDC foi observado para a aplicação dos produtos cinco dias antes + cinco dias após a inoculação. Altos teores de polifenoloxidase, peroxidase e proteínas solúveis totais foram observados nas folhas pulverizadas com pyraclostobin e ASM.

Palavras-chave: Phaseolus vulgaris, Xanthomonas axonopodis pv. phaseoli, proteína

\footnotetext{
${ }^{1}$ Prof. da Faculdade Arnaldo Horácio Pereira, FAAHF, BA. E-mail: sandracvigo@yahoo.com.br

2 Prof. da UNESP, Faculdade de Ciências Agronômicas, Dept ${ }^{\circ}$ de Produção Vegetal, Botucatu, SP. E-mail: maringoni@fca.unesp.br

${ }^{3}$ Discente de pós-graduação da UNESP, Faculdade de Ciências Agronômicas, Dept ${ }^{\circ}$ de Engenharia Rural, Botucatu, SP. E-mail: camararenata@fca.unesp.br

4 Prof. da UNESP, Instituto de Biociências, Dept ${ }^{\circ}$ de Química e Bioquímica, Botucatu, SP. E-mail: gpplima@ibb.unesp.br

* Corresponding author
} 


\section{Introduction}

Common bean bacterial blight, caused by Xanthomonas axonopodis pv. phaseoli, has great importance to common beans given its presence in almost production regions of Brazil. The symptoms occur all over the aerial part of the plant, affecting leaves, stems, snaps and seeds (BIANCHINI et al., 2005).

Induction of resistance has been under study for bacterial pathogen control since the chemical control is considered still unreliable. It involves the activation of plant latent defense mechanisms in response to treatment with biotic agents like viable or inactivated microorganisms (STANGARLIN; PASCHOLATI, 1994) or abiotics like aminobutyric acid, 2,6-dichloroisonicotinic acid and benzothiadiazoles (HALFELD-VIEIRA et al., 2006).

Plant resistance to pathogens can be and have been obtained from the application of synthetic chemical products on the plants. Induction of resistance has shown considerable progress after the development of acibenzolar-S-methyl. Since then many products have appeared that exploit the activation capability of different plant defense mechanisms like chitosan, probenazole, Oxycom and harpine among others (SOBRINHO; FERREIRA; CAVALCANTI, 2005).

Fungicides of the strobilurin group include a large variety of plant protecting synthetic compounds with a large spectrum of antifungal action. Studies have demonstrated evidence of the direct influence of strobilurines on plant physiology (KÖEHLE et al., 2002). Those physiologic effects have indicated that pyraclostrobin may also increase the resistive capability of some plants against phytopathogens attacks (HERMS et al., 2002).

This work had as goal to evaluate both the pyraclostrobin and acibenzolar-S-methyl for control of common bean bacterial blight and analysis of peroxidase, polyphenoloxidase, and total soluble proteins involved in resistance induction.

\section{Materials and Methods}

\section{Effect of chemicals on common bean bacterial blight}

Plants of snap beans cultivar Bragança were obtained in pot (3 plants/pot), at greenhouse condition, and ten days after emergence their leaves were sprayed with pyraclostrobin (Comet $\AA$ ) at concentration active ingredient $0.0375,0.075$ and $0,150 \mathrm{~mL} / \mathrm{L}$, and acibenzolar-S-methyl (Bion $\left.{ }^{\circledR}\right)$ at active ingedient $0.025 \mathrm{~g} / \mathrm{L}$. The check treatment was represented by water. All products were sprayed at timing: five days before inoculation, five days before + five days after inoculation, and five days after inoculation. Primary leaves of plants were inoculated, 15 days after emergency, by multiple needles method (ANDRUS, 1948), with bacterial suspension at $10^{8} \mathrm{UFC} / \mathrm{mL}$ of Xanthomonas axonopodis pv. phaseoli, strain (UFV-50), previous cultivated on nutrient-sucrose-agar, during $72 \mathrm{~h}$, at $28^{\circ} \mathrm{C}$. The experimental design was factorial randomized block $(5 \times 3)$ where 5 treatments (check, pyraclostrobin concentrations, and acibenzolar-Smethyl) and three spray times, with five repetitions.

The disease severity assessment on leaves was carried out 12, 15 and 18 days after inoculation using a disease severity notes (1 to 5), according Maringoni et al. (1993), computed the area under the disease progress curve - AUDPC (SCHNEIDER; WILLIAMS; SINCLAIR, 1976), and these values were submitted at variance analysis with statistical software package ASSISTAT (SILVA; AZEVEDO, 2006).

\section{Biochemical analysis}

The leaves of snap bean cultivar Bragança were sprayed with pyraclostrobin $\left(0.0750 \mathrm{~mL} . \mathrm{L}^{-1}\right)$, ASM (0.025 g.L $\left.\mathrm{L}^{-1}\right)$, and water (control). A primary leaf was collected from each repetition of noninoculated as well as of inoculated plants at five times (concomitantly, three, five, eight and ten days after leaves sprayed). The experimental design was randomized with five repetitions. 
After weighing, the leaves samples were packed and frozen in liquid nitrogen and then kept at a temperature of $-20{ }^{\circ} \mathrm{C}$. They were processed for analysis by being triturated in $5 \mathrm{~mL}$ of a $0.2 \mathrm{M}$, $\mathrm{pH} 6.7$ phosphate buffer at a temperature between $0{ }^{\circ} \mathrm{C}$ and $4{ }^{\circ} \mathrm{C}$. The resulting homogenized matter was centrifugated at 10,000, during $15 \mathrm{~min}$, at 5 ${ }^{\circ} \mathrm{C}$, (peroxidase and total soluble proteins). For evaluation of polyphenoloxidase activity a $0.05 \mathrm{M}$, pH 6.0 phosphate buffer was used in maceration. The supernatant was stored in glass flaks and kept on a freezer at $-20^{\circ} \mathrm{C}$ to be used as extract for the analysis.

The level of polyphenoloxidase was determined by method used by Cano et al. (1997), with modifications. The reaction took place in waterbath between $0.3 \mathrm{~mL}$ of stratum and $1.85 \mathrm{~mL}$ of a catechol solution $(0.1 \mathrm{M}$ pyrocatechol in a $0.05 \mathrm{M}$ $\mathrm{pH} 6.0$ phosphate buffer) for $30 \mathrm{~min}$ at $30^{\circ} \mathrm{C}$. It was interrupted after addition of $0.8 \mathrm{~mL}$ of perchloric acid at $5 \%\left(\mathrm{HClO}_{4}\right)$. The absorbance reading was carried out in a spectrophotometer with a 395 $\mathrm{nm}$ reading. The level of polypehnoloxidase was computed to obtain A.U.g ${ }^{-1}$ fresh mass min $^{-1}$.

The level of peroxidase was determined by the reaction of the extracts with solutions A (20 mM of $\mathrm{H}_{2} \mathrm{O}_{2}+0.2 \mathrm{M}$, pH 6.7 phosphate buffer) and $\mathrm{B}$ (4mM of aminoantipyrine in $10 \mathrm{mM}$ of phenol) for $5 \mathrm{~min}$ at $30^{\circ} \mathrm{C}$, the reaction being stopped with $2 \mathrm{~mL}$ of absolute ethyl alcohol immediately followed by spectrophotometric measurement at a wavelength of $505 \mathrm{~nm}$ (LIMA, 1994). The level of peroxidase was computed to obtain $\mu \mathrm{Mol} \mathrm{H}_{2} \mathrm{O}_{2}$ decomposed $\mathrm{g}^{-1}$ fresh mass $\min ^{-1}$.

The level of total soluble proteins was determinate by Bradford (1976) method by means of a reaction between an aliquot of the vegetal extract and 5 $\mathrm{mL}$ of the Bradford reactive $(100 \mathrm{mg}$ of Brilliant Blue $\mathrm{G}+50 \mathrm{~mL}$ of $95 \%$ ethanol $+100 \mathrm{~mL}$ of $85 \%$ $\mathrm{H}_{3} \mathrm{PO}_{4}+$ distilled water q.s.p. $1 \mathrm{~L}$ ) for 5 minutes, followed by absorbance spectrophotometric reading at a wavelength of $595 \mathrm{~nm}$. Values obtained from that reading were replaced in the equation of the effectiveness curve (with casein as reference) and expressed in mg protein $\mathrm{g}^{-1}$ fresh mass.

\section{Results and Discussion}

Regarding concentrations of both pyraclostrobin and ASM used in greenhouse assays to common bacterial blight, it was observed a reduction of AUDPC in plants treated with those products (Table 1). And regarding the three product application times, it was possible to observe that the least AUDPC occurred with two of those applications, five days before + five days after inoculation (Table 1). It was also observed that there was no statistical difference among AUDPC values for the different pyraclostrobin concentrations used. The pyraclostrobin dose $0.0750 \mathrm{~mL} . \mathrm{L}^{-1}$ is indicated for control of anthracnose on dry bean, in Brazil (AGROFIT, 2008). ASM and pyraclostrobin action was due to physiological resistance activators, since there has been no direct action of these products to inhibition of in vitro bacterial growth (data no showed).

Some researches have evaluated the action of ASM and pyraclostrobin in the defense of plants against bacteria. Herms et al. (2002) demonstrated that pyraclostrobin increased tobacco resistance to Tobacco mosaic virus and Pseudomonas syringae pv. tabaci. They observed accumulation of salicylic acid and of PR-1 proteins at tissues of tobacco treated with pyraclostrobin. Kuhn (2007) observed that ASM reduced the symptoms of common bacterial blight on dry beans. However, Soares and Maringoni (2002) did not find any protection when of seed and leaves of dry bean were treated with ASM on control of bacterial wilt (Curtobacterium flaccumfaciens pv. flaccumfaciens). 
Table 1. Area under the disease progress curve (AUPDC) of common bacterial blight in snap beans leaves submitted to different treatments.

\begin{tabular}{lcccc}
\hline \multirow{2}{*}{ Treatment } & \multicolumn{3}{c}{ Spray time } \\
\cline { 2 - 5 } & $\begin{array}{c}5 \text { days before } \\
\text { inoculation }\end{array}$ & $\begin{array}{c}5 \text { days before } \\
5 \text { days after } \\
\text { inoculation }\end{array}$ & $\begin{array}{c}5 \text { days after } \\
\text { inoculation }\end{array}$ & Mean \\
\hline Control (water) & 29.73 & 29.28 & 29.25 & $29.42 \mathrm{a}^{*}$ \\
Pyraclostrobin $0.0375 \mathrm{~mL} \cdot \mathrm{L}^{-1}$ & 27.27 & 25.59 & 27.24 & $26.70 \mathrm{~b}$ \\
Pyraclostrobin $0.075 \mathrm{~mL} \cdot \mathrm{L}^{-1}$ & 26.55 & 26.91 & 27.66 & $27.04 \mathrm{~b}$ \\
Pyraclostrobin 0.150 mL.L $\mathrm{L}^{-1}$ & 26.88 & 25.02 & 28.68 & $26.86 \mathrm{~b}$ \\
ASM 0.025 g L-1 & 26.76 & 26.94 & 27.18 & $26.96 \mathrm{~b}$ \\
\hline Mean & $27.44 \mathrm{ab}$ & $26.75 \mathrm{~b}$ & $28.00 \mathrm{a}$ & \\
\hline CV (\%) 5,25 & & & \\
\hline
\end{tabular}

* Means followed by the same letters do not differ significantly by the Tukey test at $5 \%$ probability.

Source: Elaboration of the authors.

In an assay involving polyphenoloxidase levels, plants treated with ASM and pyraclostrobin presented an enzyme production peak on the $5^{\text {th }}$ day after application, however pyraclostrobin presented induction already from the $3^{\text {rd }}$ day after application and remained higher than the witness until the $10^{\text {th }}$ day. Bacteria inoculation at the $5^{\text {th }}$ day after treatment with the products did not cause changes in the enzyme production on the plant, including control treatment (Figure 1). This agrees with Campos et al. (2004) who did not observe any difference in the activity of polyphenoloxidase on dry bean cultivar AB 136 (anthracnose resistant), after inoculation with the challenging fungus Colletotrichum lindemuthianum.

Li e Steffens (2002) studied the importance of polyphenoloxidase in the defense response of transgenic tomato plants which showed high levels of that enzyme. After plants were inoculated with Pseudomonas syringae pv. tomato, they showed few lesions on leaves as compared to controls, at the $7^{\text {th }}$ day after inoculation. Polyphenoloxidase catalyzes the oxidation of phenols to quinones in the presence of oxygen. The expression of that enzyme may act as an additional line of defense in the protection of plants against pathogen and insect attack (THIPYAPONG; HUNT; STEFFENS, 1995).
As for peroxidase (Figure 2), a production peak occurred for treatments with ASM and pyraclostrobin on the $8^{\text {th }}$ and $5^{\text {th }}$ days respectively, the largest level of that enzyme being found in the treatment with pyraclostrobin. There was no difference by bacterial inoculation on the $5^{\text {th }}$ day after treatment with the products but just a small increase in the plants treated with ASM and inoculated with the bacteria being seen. These results can be seen also for the total soluble proteins, indicating enzymatic activity for the plants treated with ASM and pyraclostrobin as compared to the control.

Peroxidase are important plant enzymes and is part of many reactions like polysaccharide chains, indol-3-acetic acid oxidation, monomer chains, lignification, wound cicatrization, phenol oxidation, pathogen defense, cell elongation regulation and other (KAO, 2003). Peroxidase and polyphenoloxidase lead the oxidizing degradation of phenolic compounds near the point of cellular decompartmentalization caused by pathogens. One of the most studied results of this phenomenon is the appearance of dark substances from the oxidizing polymerization of quinone (BINDSCHEDLER et al., 2002). 
Figure 1. Level of polyphenoloxidase on leaves of snap beans cultivar Bragança sprayed with water (control), pyraclostrobin $\left(0.075 \mathrm{~mL} . \mathrm{L}^{-1}\right)$ and acibenzolar-S-methyl $\left(0.025 \mathrm{~g} . \mathrm{L}^{-1}\right)$ in plants non-inoculated (A) or inoculated (B) with Xanthomonas axonopodis pv. phaseoli. The bars show means \pm standard error.
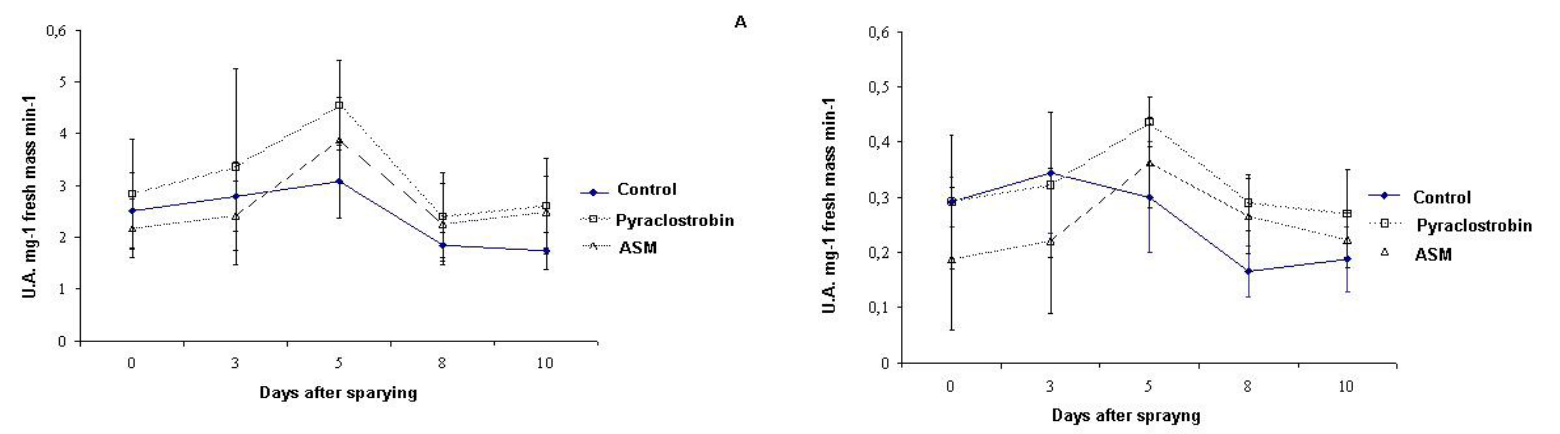

Source: Elaboration of the authors.

Figure 2. Level of peroxidase on leaves of snap beans cultivar Bragança spayed with water (control), pyraclostrobin $\left(0.075 \mathrm{~mL} . \mathrm{L}^{-1}\right)$ and acibenzolar-S-methyl $\left(0.025 \mathrm{~g} . \mathrm{L}^{-1}\right)$ in plants non-inoculated (A) or inoculated (B) with Xanthomonas axonopodis pv. phaseoli. The bars show means \pm standard error.
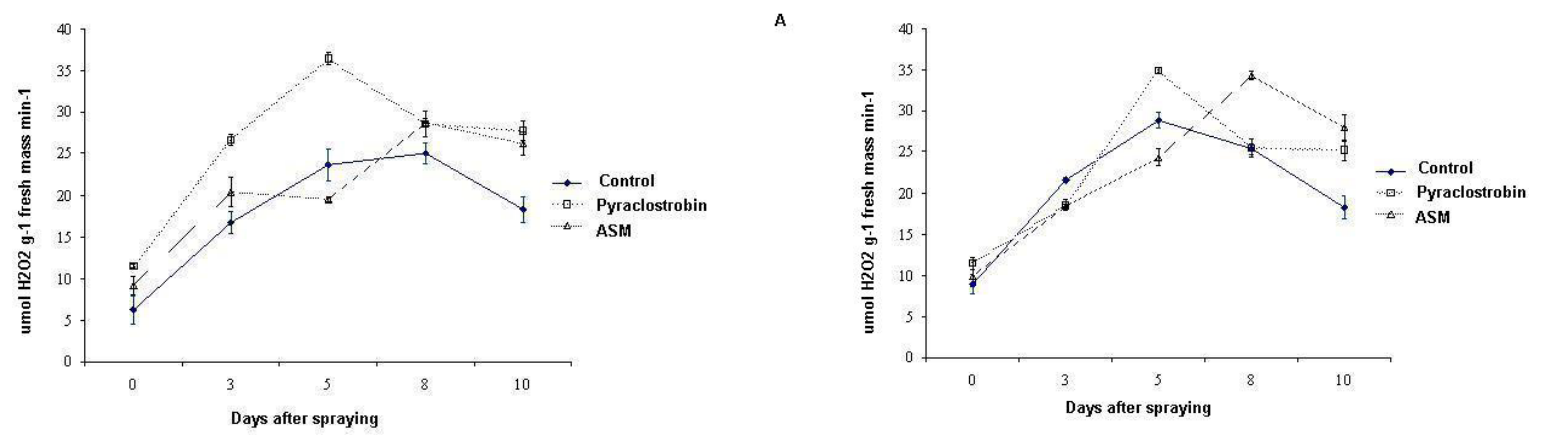

Source: Elaboration of the authors.

Cavalcanti et al. (2006) demonstrated the participation of peroxidases and oxidases of phenols in the resistance induced on tomato to Xanthomonas vesicatoria after ASM or Ecolife ${ }^{\circledR}$ sprayed. An increase in the activity of those enzymes soon after the first hours after spraying was noticed with the greatest activity occurring five days after pathogen inoculation. In the assessment of the resistance to anthracnose of four dry beans cultivars sprayed with salicylic acid or an inducting fungus, Campos et al. (2004) evaluated peroxidase and polyphenoloxidase activity of the plants treated, five days after pathogen inoculation, and verified an increase in the activity of those enzymes in the treatments with salicylic acid for all cultivars.
With respect to the level of soluble protein, an increase took place at the $3^{\text {rd }}$ day after treatments with production peaks at the $5^{\text {th }}$ and $8^{\text {th }}$ days after treatment, being that the inoculation factor at the $5^{\text {th }}$ day with these products did not cause a larger protein production (Figure 3). Silva, Pascholati and Bedendo (2007), in a bioassay conducted on the pathosystem eggplant and Ralstonia solanacearum, saw an increase in the quantity of protein in the treatment with ASM and inoculated from the third to the $12^{\text {nd }}$ days after the treatment. Our results showed that pyraclostrobin and ASM had some effect on control of common bacterial blight and increase the levels of polyphenoloxidade, peroxidase and total soluble protein on leaves of snap beans cultivar Bragança. 
Figure 3. Level of total soluble proteins on leaves of snap beans cultivar Bragança sprayed with water (control), pyraclostrobin $\left(0.075 \mathrm{~mL} . \mathrm{L}^{-1}\right)$ and acibenzolar-S-methyl $\left(0.025 \mathrm{~g} . \mathrm{L}^{-1}\right)$ in plants non-inoculated (A) or inoculated (B) with Xanthomonas axonopodis pv. phaseoli. The bars show means \pm standard error.

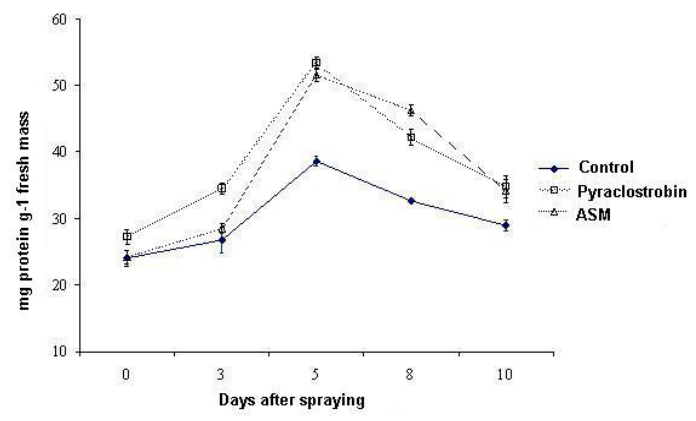

Source: Elaboration of the authors.

\section{Conclusions}

Pyraclostrobin and ASM reduced the area under the disease progress curve (AUDPC) of common bacterial blight on snap beans cultivar Bragança and higher levels of polyphenoloxidase, peroxidase and total soluble proteins were observed on leaves sprayed with pyraclostrobin or ASM.

\section{References}

AGROFIT. Sistema de agrotóxicos fitossanitários - MAPA. 2008. Disponível em: <http://extranet. agricultura.gov.br/agrofit_cons/principal_agrofit_cons>. Acesso em: 13 jun. 2008.

ANDRUS, C. F. A method of testing beans for resistance to bacterial blights. Phytopathology, St. Paul, v. 38, n. 7, p. $757-759,1948$.

BIANCHINI, A.; MARINGONI, A. C.; CARNEIRO, S. M. T. P. G. Doenças do feijoeiro. In: KIMATI, H.; AMORIM, L.; REZENDE, J. A. M.; BERGAMIN FILHO, A.; CAMARGO, L. E. A. (Ed.). Manual de fitopatologia: doenças das plantas cultivadas. São Paulo: Agronômica Ceres, 2005. v. 2, p. 333-349.

BINDSCHEDLER, L. F.; BLEE, K. A.; BUTT, V. S.; DAVIES, D. R.; GARDNER, S. L.; GERRISH, C.; MINIBAYEVA, F. The apoplastic oxidative burst in response to biotic stress in plants: a three-component system. Journal of Experimental Botany, Lancaster, v. 53, n. 372, p. 1367-1376, 2002.

BRADFORD, M. A. A rapid and sensitive method for the quantification of microgram quanties of protein

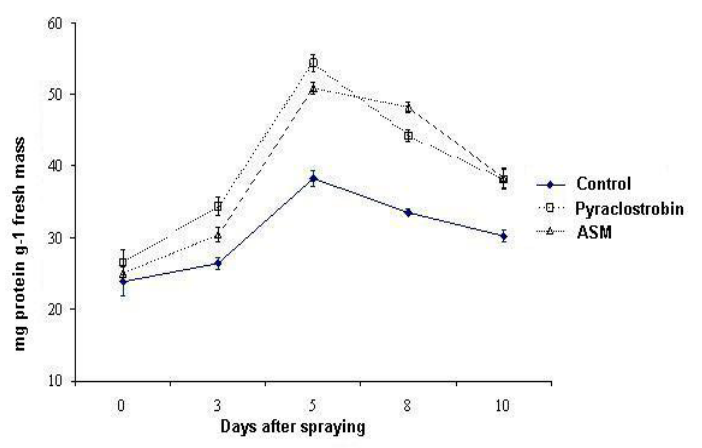

utilizing the principle of protein-dye binding. Analytical Biochemistry, New York, v. 72, n. 1/2, p. 248-254, 1976.

CAMPOS, A. D.; FERREIRA, A. G.; HAMPE, M. M. V.; ANTUNES, I. F.; BRANCÃO, N.; SILVEIRA, E. P.; OSÓRIO, V. A.; AUGUSTIN, E. Atividade de peroxidase e polifenoloxidase na resistência do feijão à antracnose. Pesquisa Agropecuária Brasileira, Brasília, v. 39, n. 7, p. 637-643, 2004.

CANO, M. P.; ANCOS, B.; MANTALLANA, M. C.; CAMARA, M.; REGLERO, G.; TABEA, J. Differences among Spanish and Latin-American banana cultivars: morphological, chemical and sensory characteristics. Food Chemistry, London, v. 59, n. 3, p. 411-419, 1997.

CAVALCANTI, F. R.; RESENDE, M. L. V.; ZACARONI, A. B.; RIBEIRO JUNIOR, P. M.; COSTA, J. C. B.; SOUZA, R. M. Acibenzolar-S-metil e Ecolife ${ }^{\circledR}$ na indução de respostas de defesa do tomateiro contra a mancha bacteriana (Xanthomonas vesicatoria). Fitopatologia Brasileira, Brasília, v. 31, n. 4, p. 372-380, 2006.

HALFELD-VIEIRA, B. A.; VIEIRA JÚNIOR, J. B.; ROMEIRO, R. S.; SILVA, H. S. A.; BARACATPEREIRA, M. C. Induction of systemic resistance in tomato by the autochthonous phylloplane resident Bacillus cereus. Pesquisa Agropecuária Brasileira, Brasília, v. 41, n. 8, p. 1247-1252, 2006.

HERMS, S.; SEEHAUS, K.; KOEHLE, H.; CONRATH, $\mathrm{U}$. A strobilurin fungicide enhances the resistance of tobacco against tobacco mosaic virus and Pseudomonas syringae pv tabaci. Plant Physiology, Rockville, v. 130, n. 2, p. 120-127, 2002.

$\mathrm{KAO}$, C. H. Differential effect of sorbitol and polyethylene glycol on antioxidant enzymes in rice 
leaves. Plant Growth Regulation, Dordrecht, v. 39, n. 1, p. 83-90, 2003.

KÖEHLE, H.; GROSSMANN, K.; JABS, T.; GERHARD, M.; KAISER, W.; GLAAB, J.; CONRATH, U.; SEEHAUS, K.; HERMS, S. Physiological effects of the strobilurin fungicide F 500 on plants. In: DEHNE, H. W.; GISI, U.; KUCK, K. H.; RUSSELL, P. E.; LYR, H. (Ed.). Modern fungicides and antifungal compounds III. Bonn: AgroConcept GmbH, 2002. p. 61-74, 2002.

KUHN, O. J. Indução de resistência em feijoeiro (Phaseolus vulgaris) por acibenzolar-S-metil e Bacillus cereus: aspectos fisiológicos, bioquímicos e parâmetros de produção. 2007. Tese (Doutorado em Agronomia) - Escola Superior de Agricultura Luiz de Queiroz, Piracicaba.

LI, L.; STEFFENS, J. C. Overexpression of polyphenol oxidase in transgenic tomato plants results in enhanced bacterial disease resistance. Planta, Berlin, v. 25, n. 2, p. 239-247, 2002.

LIMA, G. P. P. Efeito do cálcio sobre o teor de poliaminas, peroxidase e nitrato redutase em calos de arroz (Oryza sativa L. cv IAC 4440). 1994. Tese (Doutorado em Ciências Biológicas) - Instituto de Biociências. Universidade Estadual Paulista, Botucatu.

MARINGONI, A. C.; FREGONESE, L. H.; TOFOLI, J. G.; KUROZAWA, C. Reação foliar e da vagem de feijoeiro a Xanthomonas campestris pv. phaseoli e transmissão da bactéria pelas sementes. Fitopatologia Brasileira, Brasília, v. 18, n. 3, p. 412-415, 1993.

SCHNEIDER, R. W.; WILLIAMS, R. J.; SINCLAIR, J. B. Cercospora leaf spot of cowpea: models for estimating yield loss. Phytopathology, St. Paul, v. 66, n. 3, p. 384388, 1976.
SILVA, F. A. S.; AZEVEDO, C. A. V. A new version of the assistat-statistical assistance software. In: WORLD CONGRESS ON COMPUTERS IN AGRICULTURE, 4., Orlando: Anais... Orlando: American Society of Agricultural Engineers, 2006. p. 393-396.

SILVA, R. F.; PASCHOLATI, S. F.; BEDENDO, I. P. Indução de resistência em tomateiro por extratos aquosos de Lentinula edodes e Agaricus blazei contra Ralstonia solanacearum. Fitopatologia Brasileira, Brasília, v. 32, n. 3, p. 189-196, 2007.

SOARES, R. M.; MARINGONI, A. C. Efeito de acibenzolar-S-metil sobre a germinação e desempenho de sementes de feijoeiro e na indução de resistência à murcha-de-curtobacterium. Summa Phytopathologica, Jaboticabal, v. 28, n. 1, p. 41-45, 2002.

SOBRINHO, C.A.; FERREIRA, P.T. O.; CAVALCANTI, L. S. Indutores abióticos. In: CAVALCANTI, L. S.; DI PIERO, R. M.; CIA, P.; PASCHOLATI, S. F.; RESENDE, M. L. V.; ROMEIRO, R. S. (Ed.). Indução de resistência em plantas a patógenos e insetos. Piracicaba: FEALQ, 2005, p. 51-80.

STANGARlin, J. R.; PASCHOLATI, S. F. Proteção de plântulas de milho pipoca contra Exserohilum turcicum pelo uso de Saccharomyces cerevisae. Summa Phytopathologica, Jaboticabal, v. 20, n. 1/2, p. 16-21, 1994.

THIPYAPONG, P.; HUNT, M. D.; STEFFENS, J. C. Systemic wound induction of potato (Solanum tuberosum) polyphenol oxidase. Phytochemistry, Oxford, v. 40, n. 3, p. 673-676, 1995. 
